\title{
TINGKAT KEPUASAN LULUSAN TERHADAP PENYELENGGARAAN DAN MUTU LAYANAN, SERTA PERSEPSI PEMANGKU KEPENTINGAN TERHADAP KINERJA LULUSAN PROGRAM STUDI BIOLOGI FMIPA-UT
}

\author{
Susi Sulistiana ${ }^{1}$, Inggit Winarni ${ }^{1}$, Sri Kurniati ${ }^{1}$, Budi Prasetyo ${ }^{1}$ \\ Jurusan Biologi FMIPA Universitas Terbuka \\ e-mail: susi@ut.ac.id
}

\begin{abstract}
ABSTRAK
Tujuan penelitian ini adalah untuk mendeskripsikan tingkat kepuasan lulusan terhadap penyelenggaraan dan mutu layanan, serta persepsi pemangku kepentingan terhadap kinerja lulusan PS S-1 Biologi FMIPA-UT. Penelitian dilakukan pada 8 (delapan) kota UPBJJ-UT yang memiliki lulusan dan teman sejawat dari program studi Biologi. Sampel lulusan yaitu seluruh lulusan Biologi 3 tahun kebelakang pada tahun 2010 hingga 2013 sejumlah 24 lulusan. Jumlah sampel dari lulusan, atasan lulusan, dan teman sejawat adalah sebanyak 71 responden. Pengumpulan data dilaksanakan dengan metode kuantitatif melalui pengisian kuesioner atau angket dan diperdalam dengan wawancara. Data yang diperoleh dianalisis secara deskriptif. Berdasarkan hasil penelitian dapat disimpulkan bahwa penyelenggaraan program dan mutu layanan program studi umumnya sudah baik atau memuaskan bagi para lulusan. Namun demikian masih ada hal yang perlu ditingkatkan, yaitu adanya penambahan mata kuliah yang di-TTM-kan di setiap UPBJJ. Selain itu menurut persepsi pengguna lulusan, sikap dan kemampuan dan kinerja lulusan sudah baik, serta bersaing dengan perguruan tinggi lain.
\end{abstract}

Kata Kunci: mutu layanan, persepsi pemangku kepentingan, penyelenggaraan

Sebagai institusi pendidikan jarak jauh, salah satu karakteristik dari Universitas Terbuka (UT) adalah adanya keterpisahan secara fisik antara mahasiswa dengan pengajar/dosen (Bufford, 2005). Pendidikan Jarak Jauh (PJJ) mengutamakan inisiatif dan keaktifan siswa dalam proses belajar (student centered). Siswa yang memiliki kemandirian yang tinggi dalam belajar digambarkan sebagai orang yang mampu mengontrol proses belajar (Guglielmino \& Guglielmino, 1991 dikutip oleh Darmayanti, 2004).

Keberhasilan Universitas Terbuka (UT) sebagai salah satu perguruan tinggi sangat ditentukan oleh kualitas pelayanan yang diberikan, dimana pelayanan akademik yang berkualitas dapat diidentifikasi melalui kepuasan pelanggan yang dalam hal ini adalah mahasiswa. Cravens (Handayani et al., 2003) menyatakan bahwa untuk mencapai tingkat kepuasan yang tinggi, diperlukan adanya pemahaman tentang apa yang diinginkan oleh konsumen yang ada dalam lembaga untuk memenuhi kebutuhan konsumen yang bersangkutan. Ini mengindikasikan bahwa kepuasaan mahasiswa berawal dari pemahaman tentang apa yang yang diinginkan oleh mahasiswa. Salah satu hal yang sangat diperlukan oleh mahasiswa adalah pelayanan yang baik, mulai dari proses registrasi, perkuliahan, ujian sampai dengan mahasiswa menyelesaikan kuliah. Untuk menunjang hal tersebut, diperlukan perencanaan yang matang, fasilitas yang memadai, dan sumberdaya manusia yang mendukung.

Kebutuhan akan pendidikan yang bermutu dan mempunyai jangkauan luas sangat dirasakan di Indonesia. Keterbatasan kemampuan PT konvensional, khususnya PT negeri, dalam menampung calon mahasiswa makin meningkat, hal ini dapat dilihat dari jumlah pendaftar yang meningkat pada seleksi masuk PT Negeri 
pada tahun-tahun terakhir. Universitas Terbuka (UT) sebagai PTN yang didirikan pada tahun 1984 mempunyai tugas untuk menjawab permasalahan tersebut. Sedangkan Prodi S-1 Biologi FMIPA-UT diselenggarakan mulai tahun 2001 berdasarkan SK Dirjen Dikti, Nomor: 251/DIKTI/Kep/1996 (FMIPA-UT, 2010).

Program Studi Biologi FMIPA-UT sebagai salah satu bagian institusi penyedia layanan pendidikan tinggi, harus senantiasa mengutamakan kepuasan mahasiswa sebagai pelanggan dengan memberikan pelayanan terbaik. Jenis layanan PS kepada mahasiswa, meliputi tutorial tatap muka, tutorial online, layanan bimbingan administrasi akademik, bimbingan dan konseling, minat dan bakat mahasiswa (PKM, PIMNAS, mahasiswa berprestasi), beasiswa (PPA, BBM), dan bantuan layanan lainnya (pelaksanaan praktikum dan layanan pustaka). Pelayanan akademik yang baik dapat membentuk citra positif bagi UT sebagai salah satu perguruan tinggi negeri terkemuka penyedia layanan secara jarak jauh.

Istilah kinerja berasal dari kata job performance atau actual performance, yaitu prestasi kerja atau prestasi sesungguhnya yang dicapai oleh seseorang. Dalam Kamus Besar Bahasa Indonesia (1996) menerangkan bahwa kinerja mengandung arti: 1) sesuatu yang dicapai, 2) prestasi yang diperhatikan, dan 3) kemampuan kerja.

Menurut Mitchel yang dikutip Sedarmayanti dalam bukunya Sumber Daya Manusia Dan Produktivitas Kerja (2001: 51), menyebutkan aspek-aspek yang meliputi kinerja yang dapat dijadikan ukuran kinerja seseorang, yaitu sebagai berikut: 1) kualitas kerja (quality of work); 2) ketepatan waktu (promptness); 3) inisiatif (inisiative); 4) kemampuan (capability); dan 5) komunikasi (communication) (Anonim, 2014).

Menurut Anwar Prabu Mangkunegara, kinerja (prestasi kerja) adalah hasil kerja secara kualitas yang dicapai oleh seseorang pegawai dalam melaksanakan tugas sesuai dengan tanggung jawab yang diberikan kepadanya. Kinerja merupakan suatu kondisi yang harus diketahui dan dikonfirmasi kepada pihak tertentu untuk mengetahui tingkat pencapaian hasil suatu instansi dihubungkan dengan visi yang diemban oleh suatu organisasi, serta mengetahui dampak positif dan negatif dari suatu kebijakan operasional.

Dengan latar belakang yang telah diuraikan di atas, tujuan dari penelitian ini adalah untuk mendeskripsikan tingkat kepuasan lulusan terhadap penyelenggaraan dan mutu layanan, serta persepsi pemangku kepentingan terhadap kinerja lulusan PS S1 Biologi FMIPA-UT. Sedangkan manfaat yang diharapkan dari hasil penelitian ini bagi program studi Biologi adalah dapat meningkatkan penyelenggaraan dan mutu layanan, baik secara akademik maupun administrasi akademik, serta proses pembelajaran, dan masukan dari stakeholders dapat dijadikan sebagai bahan masukan program studi dalam rangka meningkatkan kualitas pendidikan dan keterampilan mahasiswa Biologi sehingga lebih siap untuk memasuki dunia kerja dan siap bersaing atau berkompetisi dengan mahasiswa dari PT yang lain.

\section{METODE PENELITIAN}

Tempat penelitian dilaksanakan di Tangerang Selatan (UT) sebagai tempat persiapan penelitian, yaitu mulai dari penyusunan proposal hingga penyusunan istrumen, serta penyelesaian penelitian, yaitu pengolahan data dan penyusunan laporan. Sedangkan pelaksanaan penelitian atau pengumpulan data dilakukan di 8 (delapan) kota UPBJJ-UT yang memiliki lulusan, atasan, dan teman sejawat dari PS S-1 Biologi, yaitu Ambon, Bandar Lampung, Bandung, Bogor, Jakarta, Purwokerto, Semarang, dan Surabaya. Penelitian dilakukan selama 9 bulan mulai awal bulan Maret hingga akhir bulan November 2014. 
Penelitian ini dilakukan melalui survei dengan melibatkan lulusan, teman sejawat, dan pengguna lulusan sebagai sumber data.

Sampel lulusan PS Biologi pada kohort (batasan target lulusan/alumni yang disurvei) 3 tahun kebelakang, meliputi lulusan tahun 2010 hingga 2013, teman sejawat, dan atasan tempat lulusan bekerja. Jumlah sampel sebanyak 71 responden, dengan perincian sebagai berikut: sampel lulusan sejumlah 24 responden, teman sejawat sejumlah 24 responden, dan atasan lulusan sejumlah 23 responden.

Pengumpulan data akan dilaksanakan dengan metode kuantitatif melalui pengisian kuesioner atau angket dan diperdalam dengan wawancara tatap muka. Penyebaran kuesioner dilakukan dengan cara tim peneliti mendatangi lulusan, teman sejawat, dan pengguna lulusan. Penyebaran kuesioner dilakukan melalui cara pengiriman pos, jasa ekspedisi, dan e-mail.

Instrumen penelitian berupa kuesioner atau angket bagi responden lulusan, teman sejawat, dan pengguna lulusan. Instrumen kuesioner dirancang dengan jawaban tertutup (berskala 1-4, misalnya untuk tingkat kepuasan: sangat kurang - sangat baik). Data yang diperoleh dari responden lulusan, teman sejawat, dan pengguna lulusan akan dianalisis secara deskriptif.

\section{HASIL DAN PEMBAHASAN}

Hasil pengumpulan data dari 71 kuesioner yang dikirimkan, sebanyak 47 kuesioner (66.20\%) kembali (terdiri atas 16 lulusan, 15 atasan, 16 teman sejawat), sebanyak 24 kuesioner $(33.80 \%)$ tidak kembali, dan dianalisis lebih lanjut. Kuesioner yang tidak kembali mungkin dikarenakan responden pindah alamat rumah, nomor HP berubah, ataupun alamat e-mailnya. Hal ini diperkuat setiap dihubungi lulusan tidak ada jawaban/balasan, baik melalui telepon maupun e-mail.

\section{Tingkat Kepuasan Lulusan terhadap Penyelenggaraan dan Mutu Layanan}

Tingkat kepuasan lulusan terhadap penyelenggaraan dan mutu layanan program studi yang meliputi: 1) aspek belajar mengajar; 2) dampak pengalaman belajar; 3) fasilitas dan kondisi belajar; 4) layanan akademik; serta 5) layanan administrasi dan akademik.

\section{Aspek Belajar Mengajar dan Dampak} Pengalaman Belajar

Dari 16 responden sebanyak 10-13 responden yang menyatakan banyak (skala 3) adalah sub variable atau komponen: pengetahuan praktis dan empiris; teori dan konsep; tutorial; bahan ajar cetak sebagai sumber utama belajar; bahan ajar non cetak (elektronik) sebagai sumber utama informasi; menulis karil atau menempuh TAP/UKT; dan ujian matakuliah teratur (Tabel 1). Begitu pula berdasar data pada Tabel 2 tentang dampak pengamalan belajar sebanyak 10-15 responden menyatakan baik (skala 3), yaitu pada ketiga sub variable atau komponen: pengetahuan, keterampilan, dan sikap. Hanya ada 1-3 lulusan yang menyatakan kurang (skala 1), yaitu dalam kemampuan berkomunikasi dengan atasan dan dalam forum informal/formal, keterampilan memanfaatkan media/sarana kerja modern, serta sikap kepercayaan diri.

Berdasar Tabel 3 menunjukkan persentase tertinggi $(81.25 \%)$ menurut responden lulusan komponen yang sudah baik adalah kualitas bahan ujian (BU), diikuti sebanyak $68.75 \%$ Ketersediaan (keterperolehan) bahan ajar, kebermanfaatan web suplemen dalam web site UT, kebermanfaatan LM/TM dalam UAS. Sedangkan persentase yang terendah $(18.75 \%)$ adalah komponen tentang koleksi buku perpustakaan di UT pusat atau di UPBJJ yang berkaitan dengan bidang studi, kualitas dari fasilitas yang disediakan UT (perpustakan, ruang diskusi, laboratorium). 
Tabel 1. Aspek Belajar Mengajar

\begin{tabular}{lcccccccc}
\hline \multicolumn{1}{c}{ Sub Variabel } & \multicolumn{3}{c}{ Frekuensi } & \multicolumn{3}{c}{ Persentase } \\
\cline { 2 - 9 } & SD & S & B & SB & SD & S & B & SB \\
\hline Pengetahuan praktis dan empiris & & 2 & 13 & 1 & & 12.5 & 81.25 & 6.25 \\
Teori dan konsep & & & 12 & 4 & & & 75 & 25 \\
Sikap dan kemampuan komunikasi & 1 & 4 & 9 & 2 & 6.25 & 25 & 56.25 & 12.5 \\
Belajar mandiri & & & 7 & 9 & & & 43.75 & 56.25 \\
Tutorial & 1 & 2 & 10 & 3 & 6.25 & 12.5 & 62.5 & 18.75 \\
Guru/tutor sebagai sumber utama informasi & 2 & 5 & 7 & 2 & 12.5 & 31.25 & 43.75 & 12.5 \\
Bahan ajar cetak sebagai sumber utama belajar & & 2 & 11 & 3 & & 12.5 & 68.75 & 18.75 \\
Bahan ajar non cetak (elektronik) sebagai sumber & & 4 & 11 & 1 & & 25 & 68.75 & 6.25 \\
utama informasi & & & & & & & & \\
Pengalaman kerja secara langsung (termasuk & 1 & 5 & 6 & 2 & 6.25 & 31.25 & 37.5 & 12.5 \\
praktek dan praktikum) & & 3 & 11 & 2 & & 18.75 & 68.75 & 12.5 \\
Menulis karil atau menempuh TAP/UKT & & 1 & 10 & 5 & & 6.25 & 62.5 & 31.25 \\
Ujian matakuliah teratur & & & & & & & & \\
\hline
\end{tabular}

Ket: SD = Sangat sedikit; S = Sedikit; B = banyak; SB = Sangat banyak

Tabel 2. Dampak Pengalaman Belajar

\begin{tabular}{|c|c|c|c|c|c|c|c|c|}
\hline \multirow{2}{*}{ Sub Variabel } & \multicolumn{4}{|c|}{ Frekuensi } & \multicolumn{4}{|c|}{ Persentase } \\
\hline & SK & $\mathrm{K}$ & $\mathrm{B}$ & SB & SK & $\mathrm{K}$ & $\mathrm{B}$ & SB \\
\hline $\begin{array}{l}\text { Pengetahuan: Kemampuan akademik atau } \\
\text { ilmu yang diperoleh }\end{array}$ & & & 13 & 3 & & & 81.25 & 18.75 \\
\hline Keterampilan: & & & & & & & & \\
\hline Kemampuan berkomunikasi dengan atasan & & 1 & 13 & 1 & & 6.25 & 81.25 & 6.25 \\
\hline $\begin{array}{l}\text { Kemampuan berkomunikasi dengan teman } \\
\text { sejawat }\end{array}$ & & & 15 & 1 & & & 93.75 & 6.25 \\
\hline $\begin{array}{l}\text { Kemampuan berkomunikasi dengan } \\
\text { bawahan }\end{array}$ & & & 12 & 2 & & & 75 & 12.5 \\
\hline $\begin{array}{l}\text { Kemampuan berkomunikasi dalam forum } \\
\text { informal/formal }\end{array}$ & & 1 & 13 & 2 & & 6.25 & 81.25 & 12.5 \\
\hline $\begin{array}{l}\text { Keterampilan menggunakan teknologi } \\
\text { yang berkaitan dengan bidang pekerjaan }\end{array}$ & 1 & & 13 & 2 & 6.25 & & 81.25 & 12.5 \\
\hline $\begin{array}{l}\text { Keterampilan memanfaatkan media/sarana } \\
\text { kerja modern }\end{array}$ & & 2 & 10 & 4 & & 12.5 & 62.5 & 25 \\
\hline $\begin{array}{l}\text { Keterampilan yang sesuai bidang ilmu } \\
\text { Sikap: }\end{array}$ & & 3 & 12 & 1 & & 18.75 & 75 & 6.25 \\
\hline Kemandirian & & & 10 & 6 & & & 62.5 & 37.5 \\
\hline Kepercayaan diri & & 1 & 10 & 5 & & 6.25 & 62.5 & 31.25 \\
\hline
\end{tabular}

Ket: $\mathrm{SK}=$ Sangat kurang; $\mathrm{K}=\mathrm{Kurang} ; \mathrm{B}=$ baik; $\mathrm{SB}=$ Sangat baik

Tabel 3. Fasilitas dan Kondisi Belajar

\begin{tabular}{|c|c|c|c|c|c|c|c|c|}
\hline \multirow{2}{*}{ Sub Variabel } & \multicolumn{4}{|c|}{ Frekuensi } & \multicolumn{4}{|c|}{ Persentase } \\
\hline & SK & $\mathrm{K}$ & $\mathrm{B}$ & SB & SK & $\mathrm{K}$ & B & SB \\
\hline Ketersediaan (keterperolehan) bahan ajar & & 2 & 11 & 3 & & 12.5 & 68.75 & 18.75 \\
\hline Kualitas bahan ajar cetak (BAC) & & 5 & 10 & 1 & & 31.25 & 62.5 & 6.25 \\
\hline Kualitas bahan ajar non-cetak (BANC) & 1 & 6 & 8 & 1 & 6.25 & 37.5 & 50 & 6.25 \\
\hline $\begin{array}{l}\text { Kebermanfaatan BANC( dalam bentuk CD) yang } \\
\text { dikemas dengan BAC }\end{array}$ & 1 & 4 & 8 & 3 & 6.25 & 25 & 50 & 18.75 \\
\hline Kebermanfaatan web suplemen dalam web site UT & & 2 & 11 & 3 & & 12.5 & 68.75 & 18.75 \\
\hline Kualitas bahan ujian (BU) & & 1 & 13 & 2 & & 6.25 & 81.25 & 12.5 \\
\hline Kebermanfaatan LM/TM dalam UAS & & 2 & 11 & 2 & & 12.5 & 68.75 & 12.5 \\
\hline $\begin{array}{l}\text { Koleksi buku perpustakaan di UT pusat atau di } \\
\text { UPBJJ yang berkaitan dengan bidang studi }\end{array}$ & & 1 & 3 & & & 6.25 & 18.75 & \\
\hline $\begin{array}{l}\text { Kualitas dari fasilitas yang disediakan UT } \\
\text { (perpustakan, ruang diskusi, laboratorium) }\end{array}$ & 2 & 6 & 3 & & 12.5 & 37.5 & 18.75 & \\
\hline
\end{tabular}

Ket: SK=Sangat kurang; $\mathrm{K}=$ Kurang;B=baik;SB=Sangat baik 
Rendahnya persentase tersebut karena sebagian besar lulusan yang berada di UPBJJ Jawa dan Ambon tidak pernah memanfaatkan/datang ke perpustakaan UT Pusat yang lokasi jauh dari tempat tinggal mereka dan membutuhkan biaya yang cukup besar. Selain itu responden memberikan masukan agar karya ilmiah mahasiswa sebaiknya dipresentasikan untuk mengetahui kekurangan dan kelebihannya sebelum diunggah dalam tuton karil. Dan secara tidak tidak langsung akan menambah peran dosen Biologi khususnya dalam mendampingi mahasiswa hingga lulus studinya.

\section{Layanan Akademik serta Layanan} Administrasi dan Akademik

Berdasarkan data hasil pengamatan dalam Tabel 4 tentang kepuasan lulusan terhadap layanan akademik bahwa sebanyak $50 \%$ responden menyatakan bahwa penyelenggaraan tutorial tatap muka (TTM) di UPBJJ masih sangat kurang, penyelenggaraan tutorial online sebanyak $75 \%$ dan kebermanfaatan tutorial online sebanyak $93.75 \%$ sudah baik-sangat baik. Sedangkan penyelenggaraan bimbingan akademik dan konseling sebanyak 56.25\%, serta sistem penilaian ujian akhir sebanyak $68.75 \%$ lulusan menyatakan sudah baiksangat baik. Dengan demikian yang masih perlu diperbaiki dalam layanan akademik ini adalah penyelenggaraan TTM di UPBJJ, salah satunya adalah dengan cara penambahan mata kuliah Biologi yang di TTM-kan di setiap UPBJJ, dan menurut lulusan diharapkan tutornya dari dosen UT pusat. Selanjutnya lulusan juga mengharapkan UT membuka program studi Biologi lebih lanjut (S2-S3).

Tabel 4. Layanan Akademik

\begin{tabular}{|c|c|c|c|c|c|c|c|c|}
\hline \multirow{2}{*}{ Sub Variabel } & \multicolumn{4}{|c|}{ Frekuensi } & \multicolumn{4}{|c|}{ Persentase } \\
\hline & SK & $\mathrm{K}$ & $\mathrm{B}$ & SB & SK & $\mathrm{K}$ & $\mathrm{B}$ & SB \\
\hline Penyelenggaraan tutorial tatap muka di UPBJJ & 8 & 3 & 5 & & 50 & 18.75 & 31.25 & \\
\hline Penyelenggaraan tutorial online & 1 & 2 & 10 & 2 & 6.25 & 12.5 & 62.5 & 12.5 \\
\hline Kebermanfaatan tutorial online & & & 9 & 6 & & & 56.25 & 37.5 \\
\hline $\begin{array}{l}\text { Bimbingan akademik dan konseling (penyapaan, } \\
\text { pemberitahuan registrasi, dll) }\end{array}$ & 3 & 4 & 8 & 1 & 18.8 & 25 & 50 & 6.25 \\
\hline $\begin{array}{l}\text { Sistem penilaian uijan akhir (kontribusi antara } \\
\text { nilai UAS dengan tuton/TTM }\end{array}$ & & 5 & 8 & 3 & & 31.25 & 50 & 18.75 \\
\hline
\end{tabular}

Ket: $\mathrm{SK}=$ Sangat kurang; $\mathrm{K}=$ Kurang;B=baik;SB=Sangat baik

Tabel 5. Layanan Administrasi dan Akademik

\begin{tabular}{|c|c|c|c|c|c|c|c|c|}
\hline \multirow[t]{2}{*}{ Sub Variabel } & \multicolumn{4}{|c|}{ Frekuensi } & \multicolumn{4}{|c|}{ Persentase } \\
\hline & SK & $\mathrm{K}$ & $\mathrm{B}$ & SB & SK & $\mathrm{K}$ & $\mathrm{B}$ & SB \\
\hline $\begin{array}{l}\text { Penanganan keluhan mahasiswa (kasus nilai, } \\
\text { registrasi) tingkat Prodi }\end{array}$ & 1 & 1 & 11 & 3 & 6.25 & 6.25 & 68.75 & 18.75 \\
\hline $\begin{array}{l}\text { Penanganan keluhan mahasiswa (kasus nilai, } \\
\text { registrasi) tingkat UPBJJ }\end{array}$ & 1 & 3 & 10 & 2 & 6.25 & 18.75 & 62.5 & 12.5 \\
\hline $\begin{array}{l}\text { Layanan prodi terhadap keluhan Anda melalui } \\
\text { sms/ email/forum komunitas/datang langsung }\end{array}$ & & 2 & 10 & 4 & & 12.5 & 62.5 & 25 \\
\hline
\end{tabular}

Ket: $\mathrm{SK}=$ Sangat kurang; $\mathrm{K}=$ Kurang;B=baik;SB=Sangat baik

Sedangkan kepuasan lulusan terhadap layanan administrasi dan akademik (Tabel 5) tentang penanganan keluhan mahasiswa tingkat prodi sebanyak 14 lulusan menyatakan sudah baik-sangat baik (skala 3-4) dan sebanyak 16 lulusan mengungkapkan bahwa penanganan keluhan mahasiswa tingkat UPBJJ dan layanan prodi terhadap keluhan lulusan sudah baik-sangat baik (skala 3-4) pula. Namun demikian ada satu UPBJJ tertentu (daerah Jawa Tengah) yang kurang ramah (tidak senyum sapa salam) dalam menangani keluhan mahasiswa/lulusan. 
Responden juga memberikan saran agar ada pelayanan administrasi dan akademik pada hari libur/minggu di UPBJJ dengan cara adanya petugas piket secara bergiliran. Selanjutnya berdasar data pengamatan dari 16 lulusan hanya 1 orang yang mendapatkan beasiswa/bantuan belajar mahasiswa (BBM) pada tahun 2007-2009. Begitu pula untuk beasiswa PPA yang berdasar indeks prestasi akademik/IPK
(>2.75) tidak ada karena semua lulusan IPK nya rata-rata hanya mencapai $<2.75$.

\section{Persepsi Pemangku Kepentingan terhadap Kinerja Lulusan}

Hasil penelitian tentang Persepsi Pemangku Kepentingan terhadap Kinerja Lulusan $(\mathrm{N}=15$ responden atasan / pengguna lulusan) disajikan dalam Tabel 6 dan 7.

Tabel 6. Kualitas Kinerja: Sikap dan Kemampuan (N=15 responden atasan)

\begin{tabular}{|c|c|c|c|c|c|c|c|c|c|}
\hline \multirow{2}{*}{ Sub Variabel } & \multicolumn{5}{|c|}{ Frekuensi } & \multicolumn{4}{|c|}{ Persentase } \\
\hline & SK & $\mathrm{K}$ & $\mathrm{B}$ & SB & $\mathrm{Jml}$ & SK & $\mathrm{K}$ & $\mathrm{B}$ & SB \\
\hline \multicolumn{10}{|l|}{ Kemampuan untuk pengembangan diri } \\
\hline Minat untuk mengikuti studi lanjut & & & 10 & 4 & 14 & & & 66.67 & 26.67 \\
\hline Minat untuk mengikuti pelatihan & & & 7 & 7 & 14 & & & 46.67 & 46.67 \\
\hline Pemanfaatan internet untuk pengembangan diri & & 1 & 7 & 6 & 14 & & 6.67 & 46.67 & 40.00 \\
\hline \multicolumn{10}{|l|}{ Kepemimpinan } \\
\hline Perencanaan & & & 11 & 3 & 14 & & & 73.33 & 20.00 \\
\hline Pengelolaan & & & 11 & 3 & 14 & & & 73.33 & 20.00 \\
\hline Monitoring dan evaluasi & & & 11 & 3 & 14 & & & 73.33 & 20.00 \\
\hline \multicolumn{10}{|l|}{ Keтатриап mengajar } \\
\hline $\begin{array}{l}\text { Keterampilan dasar mengajar (membuka } \\
\text { menutup pelajaran, dll }\end{array}$ & & & 2 & 2 & 4 & & & 13.33 & 13.33 \\
\hline Merancang pembelajaran & & & 2 & 2 & 4 & & & 13.33 & 13.33 \\
\hline Menggunakan media dan alat peraga & & & 3 & 1 & 4 & & & 20.00 & 6.67 \\
\hline Menggunakan strategi pembelajaran yang tepat & & & 2 & 2 & 4 & & & 13.33 & 13.33 \\
\hline Melaksanakan penelitian tindakan kelas & & & 3 & 1 & 4 & & & 20.00 & 6.67 \\
\hline Menguasai materi & & & 2 & 2 & 4 & & & 13.33 & 13.33 \\
\hline Melaksanakan evaluasi & & & & 3 & 3 & & & & 20.00 \\
\hline Membimbing atau memotivasi siswa & & & & 3 & 3 & & & & 20.00 \\
\hline
\end{tabular}

Tabel 7. Kualitas Kinerja: Kinerja Lulusan (N=15 responden atasan)

\begin{tabular}{|c|c|c|c|c|c|c|c|c|c|}
\hline \multirow{2}{*}{ Sub Variabel } & \multicolumn{5}{|c|}{ Frekuensi } & \multicolumn{4}{|c|}{ Persentase } \\
\hline & SK & $\mathrm{K}$ & $\mathrm{B}$ & SB & Jml & SK & $\mathrm{K}$ & $\mathrm{B}$ & SB \\
\hline \multicolumn{10}{|l|}{ Perilaku inovatif } \\
\hline Frekuensi memberikan ide/usul dalam pekerjaan & & 1 & 8 & 4 & 13 & & & 53.33 & 26.67 \\
\hline Frekuensi ide/usul diterima & & 1 & 9 & 4 & 14 & & & 60.00 & 26.67 \\
\hline $\begin{array}{l}\text { Frekuensi melakukan hal-hal yang bersifat } \\
\text { inovatif }\end{array}$ & & 1 & 10 & 2 & 13 & & & 66.67 & 13.33 \\
\hline \multicolumn{10}{|l|}{ Tanggung jawab } \\
\hline Penyelesaian tugas tepat waktu & & & 8 & 5 & 13 & & & 53.33 & 33.33 \\
\hline Hasil pekerjan berkualitas baik & & & 9 & 4 & 13 & & & 60.00 & 26.67 \\
\hline \multicolumn{10}{|l|}{ Kontribusi terhadap institusi } \\
\hline Kontribusi terhadap kebutuhan institusi & & 1 & 8 & 4 & 13 & & & 53.33 & 26.67 \\
\hline \multicolumn{10}{|l|}{$\begin{array}{l}\text { Dlm } 5 \text { thn apakah staf Anda pernah menerima } \\
\text { penghargaan }\end{array}$} \\
\hline ya & & & & & 4 & & & 26.67 & \\
\hline tidak & & & & & 6 & & & 40.00 & \\
\hline \multicolumn{10}{|l|}{ Prestasi bidang pekerjaan } \\
\hline \multicolumn{10}{|l|}{2 prestasi terbaik ( 5 tahun terakhir) } \\
\hline Jumlah prestasi & & & $3 x, 1$ & & & & & 20.00 & \\
\hline
\end{tabular}


Dalam Tabel 6 dan 7 terlihat bahwa kemampuan pengembangan diri dalam minat untuk mengikuti studi lanjut sebanyak $66.67 \%$ dan kepemimpinan lulusan UT yang meliputi perencanaan, pengelolaan, monitoring dan evaluasi sebesar $73.33 \%$ responden menyatakan baik. Sedangkan kemampuan mengajar, perilaku inovatif yaitu dalam memberikan ide dan usul yang diterima, tanggung jawab, kontribusi terhadap kebutuhan institusi, prestasi bidang pekerjaan bagi lulusan UT umumnya masih kurang, yaitu persentasenya rata-rata $<60 \%$ yang memiliki kualitas kinerja yang baik. Masih kurangnya kemampuan lulusan dalam mengajar karena sebagian besar lulusan bukan berlatar belakang guru tetapi mereka berlatang belakang dari di bidang non kependidikan, seperti analis kesehatan dan laboran di laboratorium rumah sakit. Hanya 4 lulusan yang bekerja di bidang pendidikan yaitu sebagai guru dan dosen perguruan tinggi negeri.

Sedangkan dalam hal kerja sama (Tabel 8), sebanyak 10 orang atasan menyatakan bahwa dalam menyelesaikan pekerjaan, lulusan melakukannya dengan teman sejawat dan sebanyak 8 orang atasan menyatakan lulusan UT sering dilibatkan dalam kerja kelompok.

Tabel 8. Kualitas Kinerja: Kerjasama (N=15 responden atasan)

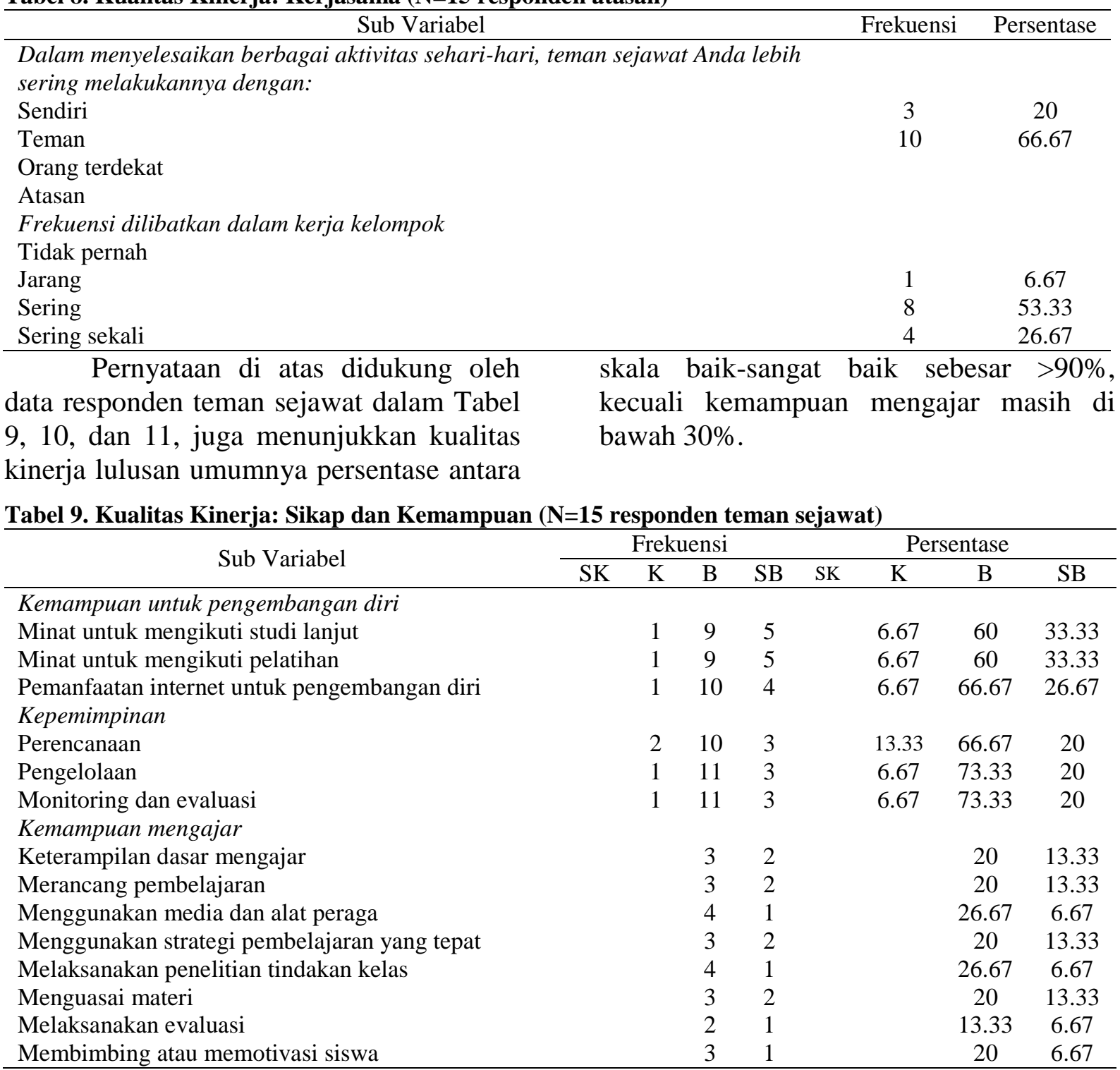

Ket: $\mathrm{SK}=$ Sangat kurang; K=Kurang; $\mathrm{B}=$ baik; SB=Sangat baik 
Tabel 10. Kualitas Kinerja: Kinerja Lulusan ( $N=15$ responden teman sejawat)

\begin{tabular}{|c|c|c|c|c|c|c|c|c|}
\hline \multirow{2}{*}{ Sub Variabel } & \multicolumn{4}{|c|}{ Frekuensi } & \multicolumn{4}{|c|}{ Persentase } \\
\hline & SK & $\mathrm{K}$ & $\mathrm{B}$ & SB & SK & $\mathrm{K}$ & $\mathrm{B}$ & SB \\
\hline \multicolumn{9}{|l|}{ Perilaku inovatif } \\
\hline Frekuensi memberikan ide/usul dalam pekerjaan & & 1 & 11 & 3 & & 6.667 & 73.33 & 20 \\
\hline Frekuensi ide/usul diterima & & 2 & 10 & 3 & & 13.33 & 66.67 & 20 \\
\hline $\begin{array}{l}\text { Frekuensi melakukan hal-hal yang bersifat } \\
\text { inovatif }\end{array}$ & & 3 & 10 & 2 & & 20 & 66.67 & 13.33 \\
\hline \multicolumn{9}{|l|}{ Tanggung jawab } \\
\hline Penyelesaian tugas tepat waktu & & 1 & 10 & 4 & & 6.667 & 66.67 & 26.67 \\
\hline Hasil pekerjan berkualitas baik & & 1 & 10 & 4 & & 6.667 & 66.67 & 26.67 \\
\hline \multicolumn{9}{|l|}{ Kontribusi terhadap institusi } \\
\hline Kontribusi terhadap kebutuhan institusi & & & 13 & 2 & & & 86.67 & 13.33 \\
\hline $\begin{array}{l}\text { Kontribusi terhadap kemajuan institusi/tempat } \\
\text { kerja }\end{array}$ & & 1 & 12 & 2 & & 6.667 & 80 & 13.33 \\
\hline
\end{tabular}

Tabel 11. Kualitas Kinerja: Kerjasama (N=15 responden teman sejawat)

\begin{tabular}{lcc}
\hline Sub Variabel & Frekuensi & Persentase \\
\hline Dalam menyelesaikan berbagai aktivitas sehari-hari, teman sejawat Anda lebih & & \\
sering melakukannya dengan: & 5 & 33.33 \\
Sendiri & 9 & 60 \\
Teman & 1 & 6.667 \\
Orang terdekat & & \\
Atasan & & \\
Frekuensi dilibatkan dalam kerja kelompok & 5 & 33.33 \\
Tidak pernah & 5 & 46.67 \\
Jarang & 7 & 20 \\
Sering & 3 & \\
Sering sekali & 3 \\
\hline
\end{tabular}

Kinerja lulusan yang baik kemungkinan disebabkan salah satunya adalah kepuasan kerja lulusan terhadap pimpinan/perusahaan. Menurut Brahmasari dan Suprayetno (2008), mengemukakan kepuasan kerja dapat tercipta jika variabel-variabel yang mempengaruhinya, antara lain motivasi kerja, kepemimpinan dan budaya organisasi perusahaan dapat diakomodasikan dengan baik dan diterima oleh semua karyawan di dalam suatu organisasi/perusahaan.

Kepuasan karyawan akan mendorong tumbuhnya loyalitas karyawan pada organisasi. Selanjutnya loyalitas karyawan akan mengarah pada peningkatan produktifitas. Produktifitas karyawan mendorong penciptaan nilai pelayanan external yang kemudian menentukan kepuasan pelanggan external, karena kepuasan pelanggan merupakan salah satu faktor penentu loyalitas pelanggan (Anonim, 2013).

Mink mengemukakan pendapatnya bahwa individu yang memiliki kinerja yang tinggi memiliki karakteristik, diantaranya a) berorientasi pada prestasi, b) memiliki percaya diri, c) berpengendalian diri, dan d) kompetensi (Anonim, 2014).

\section{KESIMPULAN DAN SARAN}

\section{Kesimpulan}

Penyelenggaraan program dan mutu layanan program studi umumnya sudah baik atau memuaskan bagi para lulusan. Namun demikian masih ada hal yang perlu ditingkatkan, yaitu adanya penambahan mata kuliah yang di-TTM-kan di setiap UPBJJ. Peningkatan pelayanan UPBJJ tertentu (daerah Jawa Tengah) karena kurang ramah terhadap mahasiswa/lulusan. Sedangkan persepsi pengguna lulusan 
menyatakan kinerja lulusan sudah baik, tetapi kemampuan mengajar yang masih perlu ditingkatkan.

\section{Saran}

Perlu adanya perbaikan sistem dalam mengupdate data mahasiswa yang registrasi hingga lulus. Juga perlu adanya pelayanan administrasi dan akademik di UPBJJ (petugas piket secara bergiliran) pada hari libur (minggu) untuk mengakomodasi mahasiswa yang bekerja hingga hari sabtu.

\section{DAFTAR RUJUKAN}

Anonim. 2013. Definisi kepuasan menurut para ahli. (Online). http://www.refe rensimakalah.com/2013/03/definisi-

kepuasan-menurut-para-

ahli.html $? m=$ Diambil 12 Februari 2014.

Anonim. 2014. Indikator kinerja. (Online). www.scribd.com/doc/97171931/indik ator kinerja. Diambil 6 Februari 2014.

Anonim. 2014. Kinerja pegawai menurut Sedarmayanti. (Online). http://ww w.scribd.com/doc/35390443/KinerjaPegawai-menurut-Sedarmayanti. Diambil 6 Februari 2014.

Anonim. 2014. Indikator kinerja. (Online). www.scribd.com/doc/97171931/indik ator kinerja. Diambil 6 Februari 2014.

Brahmasari, I.A. \& Suprayetno, A. 2008. Pengaruh motivasi kerja, kepemimpinan dan budaya organisasi terhadap kepuasan kerja karyawan serta dampaknya pada kinerja perusahaan (Studi kasus pada PT. Pei Hai International Wiratama Indonesia). Jurnal Manajemen dan Kewirausahaan, 10(2): 124-135.

Bufford, J. Jr. 2005. An introduction to designing and delivering courses and programs at a distance, advance methods in distance education: Applications and practices for educators,administrators and learners. eds. K.E. Dooley, J.R. Lindner, \& L.M. Dooley. London:Yurchack Printing Inc.

Darmayanti, T. 2004. Pengembangan tutorial melalui media telepon pada pendidikan jarak jauh (studi kasus di FISIP Universitas Terbuka). Jurnal Pendidikan Terbuka dan Jarak Jauh. 5 (2): 108-127.

FMIPA-UT. 2010. Evaluasi diri program studi sarjana biologi. Jakarta: FMIPA-UT.

Handayani, R, Yermias T. K., \& Ratminto. 2003. Analisis kepuasan pemakai terhadap pelayanan perpustakaan nasional provinsi daerah istimewa Yogyakarta. Sosiosains, vol 17(2), April 2003. Pasca Sarjana Fisipol UGM, Yogyakarta. 